Tymkiv Oleksandr,

National University Odessa Maritime Academy, postgraduate student, Marine Engineering Faculty

E-mail:dvg.smc@gmail.com

\title{
WAYS TO IMPROVE SHIP POWER PLANTS
}

Abstract. The article considers a method for evaluating the effectiveness of potential and actual capabilities of vehicles and systems utilization. It is shown that for ships, the reserves for improving the use of the transport potential associated with ship power plants are characterized by such an parameter as the loss factor of the transport work from incomplete use of speed.

Keywords: reliability of power plants, transport potential, transport performance

Modern ship companies are constantly increasing demands on the safety of navigation. It is possible to meet their demands by increasing reliability of ship power plants (SPP) that work in specific and extreme conditions (oscillating motion, storm, lack of professional assistance from onshore repair bases, etc.). Improving the reliability and safety of SPP is a complex task that is solved both during manufacture and during operation. Timely detection of the deviations from the operational value and prevention of failure accidents are one of the most important component for SPP technical operation [1].

The long-term trend for increase in energy prices predetermines a share of fuel costs escalation in total operating costs of ship owners. Concurrently, environmental safety requirements are toughening, which makes it necessary to prevent even economically insignificant failures of the SPP if they are associated with a risk to the vessel and the environment. In this regard, the SPP technical operation development is a range of important scientific and technical issues.

An overview of the development trend of SPP technical operation in historical retrospect shows that the effectiveness of their solution is largely determined by the mutual compliance of technological and information processes. Ensuring such compliance is particularly important [2].

An analysis of the current state of these issues have revealed that they are solved at the level of individual technical issues: fuel and oil economy; technical condition maintenance of various technical equipment and systems of the ship; reduction of maintenance and repair complexity, etc. Despite the wide scope of research conducted in this direction by domestic and foreign experts, their overall progress is not very high [3].

There are many reasons that determine this predicament, but one of the most crucial is the contradiction between the high complexity and diversity of SPP equipment, high amount of information on its functioning and technical condition on the one hand, and the limited capabilities of shipboard specialists to analyze this information. As a result of the consistent reduction in the number of ship crews and the need to combine the professions of the deck and machine teams, these opportunities are on decrease.

For further analysis of the SPP technical use and their importance for the overall improvement of the efficiency of the fleet, it is necessary to be able to comprehensively evaluate this effectiveness. The performed transport work to the theoretically possible transport work in the case of full use of the passport characteristics of the vehicle ratio. For brevity, this ratio is called the transport potential utilization factor $\gamma$. Its analytic form can be obtained on the following basis [4].

It is known that the system of transport meters can be constructed on the basis of three basic units: 
1) transport mass $\mathrm{Q} ; 2$ ) transport route $\mathrm{L} ; 3$ ) transport time $T$.

Then the characteristic of the transport system of any level can be considered the transport work $A$. $A=Q L$.

For the subsequent analysis it is more convenient to express $L$ in terms of speed $V$ and time $T$. Then the dependence is as follows

$$
A=Q V T .
$$

On a practical level the factual transport work is expressed as:

$$
F=Q^{f} V^{f} T^{f}=\rho^{Q^{p}} \delta^{V^{p}} \alpha \beta \cdot(1-\lambda) T,
$$

where $Q^{p}$ is the nominal tonnage, tonn;

$V^{p}$ is the nominal speed, $\mathrm{km} / \mathrm{h}$;

$T$ - transport uptime, h;

$T^{f}$ - factual transport operation time, h;

$Q^{f}$ - factual used tonnage (cargo performance), tonn;

$V^{f}$ - vehicle technical speed, $\mathrm{km} / \mathrm{h}$;

$\rho=\frac{Q^{f}}{Q^{p}}-$ is the tonnage factor;

$\delta=\frac{V^{f}}{V^{p}}-$ is the speed utilization factor;

$\alpha=\frac{T^{f}}{T}-$ is the uptime utilization factor;

$\beta=\frac{T^{m}}{T}-$ is the steaming time utilization factor ( $T^{m}$ - is the ship motion time, h);

$\lambda=\frac{T^{b}}{T^{m}}-$ is the ballast passage factor $\left(T^{b}-\right.$ is the ship ballast passage time, $h$ ).

Without losses (i.e. in the ideal case)

$$
\rho=1, \quad \delta=1, \quad \alpha=1, \quad \beta=1, \quad \lambda=0,
$$

and potential transport work will be described by

$$
P=Q^{p} V^{p} T,
$$

with identical structure to (1).

Then the transport potential utilization factor:

$$
\gamma=F / P .
$$

For a single vehicle (ship) it is obviously:

$$
\gamma=\rho \delta \alpha \beta \cdot(1-\lambda) \text {. }
$$

For $n$ same type vehicle system the transport potential utilization factor will be calculated by the following formula for general case:

$$
\gamma=\sum_{i=1}^{n} \gamma_{i} I_{i}=\sum_{i=1}^{n} \rho_{i} \delta_{i} \alpha_{i} \beta_{i}(1-\lambda) I_{i},
$$

where $I_{i}=\frac{Q_{i}^{p} V_{i}^{p} T_{i}}{\sum_{i=1}^{n} Q_{i}^{p} V_{i}^{p} T_{i}}$ - weight factor of $i$ vehicles.

The proposed factor allows you to quantify effectiveness of the operation of both potential and actual capabilities of vehicles and systems. The case of a transportation system with $\gamma=1$ can be considered a pipeline through which oil or gas is continuously pumped over the period $\mathrm{T}$ at a design rate [5]. Low values of the transport potential utilization in the general case will indicate the irrational use of transport and the insufficiently substantiated design of vehicles. For a single vehicle, the method of calculating $\rho, \delta, \alpha, \beta$ and $\lambda$ factors is obvious by definition. They are similar to the known load factor $\rho$, speed utilization factor $\delta$, uptime utilization factor $\beta$ etc., which are widely used in the reporting documentation and in statistical reviews. As a result, for $n$ transports with different nominal parameters we get:

$$
\begin{gathered}
\rho=\sum_{i}^{n} \rho_{i} I_{i} ; \quad \delta=\sum_{i}^{n} \delta_{i} I_{i} ; \quad \alpha=\sum_{i}^{n} \alpha_{i} I_{i} ; \\
\beta=\sum_{i}^{n} \beta_{i} I_{i} ; \quad \lambda=\sum_{i}^{n} \lambda_{i} I_{i} .
\end{gathered}
$$

In general, the analysis of transport work parameters is performed for the reporting period. In this case, the transport uptime for all transport units is the same and the weight factors in formulas (3) are reduced to

$$
I_{i}=\frac{Q_{i}^{p} V_{i}^{p}}{\sum_{i=1}^{n} Q_{i}^{p} V_{i}^{p}} .
$$

The calculations show that evaluation of the transport potential utilization of the main types of generalpurpose transport range from $4 \%$ for river transport to $20 \%$ for maritime transport (Table 1). 
Table 1.- Estimates of the potential utilization of different transport types

\begin{tabular}{|l|c|c|c|c|}
\hline \multirow{2}{*}{\multicolumn{1}{|c|}{ Parameter }} & \multicolumn{4}{c|}{ Transport types,\% } \\
\cline { 2 - 5 } & river & road & railroad & sea \\
\hline $\begin{array}{l}\text { Transport potential utilization fac- } \\
\text { tor }\end{array}$ & 4.1 & 5.4 & 7.4 & 18.0 \\
\hline Potential losses of: & & & & \\
\hline tonnage & 16.4 & 10.7 & - & 22.6 \\
\hline speed & 23.4 & 33.8 & 40.1 & 17.1 \\
\hline uptime & 17.4 & - & - & - \\
\hline steaming time & 21.9 & 33.5 & 52.5 & 23.3 \\
\hline ballast passage & 15.0 & 16.6 & - & 19.0 \\
\hline
\end{tabular}

From the analysis of the data in (Table 1) and the structure of formula (2) it follows that for sea ships, the reserves for improving the transport potential are characterized by the loss rate of the transport work due to under-utilization of speed. The mean value is $17 \%$.

These reserves are indirectly and partially associated with the loss of transport work from underutilization of tonnage and the loss of transport work from non-compliance of the operating time with the uptime (decommissioning the vessel to repair SPP if necessary). However, their quantitative evaluation of available data is difficult.

\section{References:}

1. Golikov V.A. A simple technique for identifying vessel model parameters / V. A. Golikov, V. V. Golikov, Ya. Volyanskaya, O. Mazur, O. Onishchenko // $4^{\text {th }}$ International Scientific Conference SEA-CONF 2018. IOP Conf. Series: Earth and Environmental Science 172 (2018) 012010 doi:10.1088/17551315/172/1/012010.

2. Kuropyatnyk O.A. Reduction of $\mathrm{NO}_{\mathrm{x}}$ emission in the exhaust gases of low-speed marine diesel engines / O.A. Kuropyatnyk //Austrian Journal of Technical and Natural Sciences,- Vienna-2018.- No. 7-8 (July-August).- P. 37-42. doi.org/10.29013/AJT-18-7.8-37-42.

3. Тымкив А.В. Методы и среАства Аиагностирования судовой энергетической установки / А. В. Тымкив, В. Г. Аенисов / / Судовые энергетические установки: науч.-техн. сб., 2013.- Вып. 32.C. $113-123$.

4. Тымкив А. В. Мониторинг процесса изнашивания судовой энергетической установки / А. В. Тымкив, В.Г. Аенисов // Судовые энергетические установки: ОАесса, 2014.- Вып. 33.- С. 88-96.

5. Sagin S. V. Improving the performance parameters of systems fluids / S. V. Sagin // Austrian Journal of Technical and Natural Sciences,- Vienna-2018.- № 7-8 (July-August).- P. 55-59. doi.org/10.29013/ AJT-18-7.8-55-59. 